J. Dairy Sci. 99:3667-3674

http://dx.doi.org/10.3168/jds.2015-10538

(C) American Dairy Science Association ${ }^{\circledR}, 2016$.

\title{
Citrus-derived oil inhibits Staphylococcus aureus growth and alters its interactions with bovine mammary cells
}

\author{
C. Federman, ${ }^{*}$ J. Joo, ${ }^{*}$ J. A. Almario, ${ }^{*}$ S. Salaheen, ${ }^{*}$ and D. Biswas ${ }^{*}{ }^{1}$ \\ *Department of Animal and Avian Sciences, and \\ †Center for Food Safety and Security Systems, University of Maryland, College Park 20742
}

\begin{abstract}
This experiment examined the effects of cold-pressed, terpeneless citrus-derived oil (CDO) on growth of Staphylococcus aureus, which a major cause of contagious bovine mastitis, and invasion of bovine mammary cells (MAC-T). To determine minimum inhibitory concentration, we used the broth dilution method, using CDO concentrations range from 0.0125 to $0.4 \%$ with 2 -fold dilutions. Growth inhibition was examined by adding $0.00,0.05,0.025,0.0125$, and $0.00625 \% \mathrm{CDO}$ to $10^{5} \mathrm{cfu} / \mathrm{mL} S$. aureus in nutrient broth and enumerating colonies after serial dilution. In a 96 -well plate, S. aureus $\left(10^{7} \mathrm{cfu} / \mathrm{mL}\right)$ was allowed to form a biofilm, treated with $0,0.025,0.5$, or $1 \% \mathrm{CDO}$, and then was measured using a spectrophotometer. Cytotoxic effect on immortalized MAC-T cells was also examined at various concentrations of CDO using a 3-(4,5-dimethylthiazol-2-yl)-2,5-diphenyltetrazolium bromide assay. We observed that the minimum inhibitory concentration of CDO to inhibit the growth of $S$. aureus in vitro was $0.025 \%$ CDO. A time kill curve for CDO action on $S$. aureus over $4 \mathrm{~h}$ was generated. The CDO completely eliminated $S$. aureus after $3 \mathrm{~h}$ of incubation at a concentration of $0.25 \%$, or after $2 \mathrm{~h}$ of incubation at concentrations of $0.05 \%$. It was also observed that CDO had no effect on preformed biofilms except at a concentration of $0.05 \%$, in which a significant reduction in the measured absorbance was noted. In addition, the association and invasion of $S$. aureus to MAC-T cells were significantly inhibited after $1 \mathrm{~h}$ of treatment with CDO. Citrus-derived oil was also able to increase cellular proliferation of MAC-T cells at concentrations up $0.05 \%$ and had no effect at a concentration of $0.1 \%$ after $1 \mathrm{~h}$. Our data suggests that CDO should be considered for further research as a preventive and therapeutic against bovine mastitis.
\end{abstract}

Received October 19, 2015.

Accepted January 1, 2016.

${ }^{1}$ Corresponding author: dbiswas@umd.edu
Key words: antibiofilm, citrus oil, inhibition, mastitis, Staphylococcus aureus

\section{INTRODUCTION}

Mastitis, an inflammation of the mammary gland, is one of the most costly diseases affecting dairy farming, exceeding $\$ 2$ billion annually, with economic losses resulting from premature culling, additional labor, management, and veterinary costs, and reduced milk production and quality (Seegers et al., 2003; Bar et al., 2008). This cost excludes irreversible damage to the mammary gland that can lead to future reduced milk production, milk composition changes, and reproductive inefficiency from cows with mastitis (Harmon, 1994).

Mastitis is characterized by an increase in milk SCC and may be accompanied by the presence of an intramammary pathogen (Paape et al., 2003). The most common bacteria associated with mastitis are Staphylococcus species, Streptococcus species, and coliforms, such as Escherichia coli and Corynebacterium. Staphylococcus species, specifically Staphylococcus aureus, are considered more virulent and the most damaging causative agent (Reyher et al., 2012). Mastitis can be clinical or subclinical; clinical mastitis is characterized by abnormal milk secretions with or without local or systemic signs of inflammation, whereas subclinical mastitis has a higher incidence rate and is most commonly diagnosed by the presence of a pathogen in milk (Barlow, 2011). Subclinical mastitis is the most common form of mastitis but is asymptomatic, and therefore may go undetected (Barlow, 2011). A recent surveillance study showed that $S$. aureus is also the main cause for subclinical mastitis (Botrel et al., 2010; Moser et al., 2013). Antibiotic treatment is widely used to treat clinical mastitis caused by $S$. aureus. However, antibiotic use is controversial not only due to economic relevance, but also growing consumer concerns (Moser et al., 2013). Treatment of the causative bacteria using antibiotics is coming under increasing public scrutiny due to the possible development of resistant pathogens 
(Craven, 1987; Guterbock et al., 1993) and risk of residues appearing in the milk. One study, which included conventional dairy farms in New York, found S. aureus resistance to ampicillin, erythromycin, penicillin, and tetracycline to be common among isolates obtained from mastitic milk (Tikofsky et al., 2003). In addition, cure rates using antibiotics for $S$. aureus mastitis vary considerably, ranging from 4 to $92 \%$ (Barkema et al., 2006). A study on clinical mastitis cases in the Netherlands found a cure rate of only 52\% (Sol et al., 2000). Thus, alternative strategies for control and treatment for $S$. aureus is essential for improving animal health and economic outcome for the farmer (Barkema et al., 2006).

Many plant derivatives and essential oils derived from the citrus fruits and other plants contain secondary metabolites that can inhibit bacterial growth (Burt and Reinders, 2003; Burt, 2004). Essential oils, or fractions thereof, have been traditionally used as flavoring agents in foods, and it has frequently been noted that many possess antimicrobial properties (Smith-Palmer et al., 1998; Alzoreky and Nakahara, 2003; Ahn et al., 2014; Salaheen et al., 2014a; Yang et al., 2014; Budri et al., 2015). One past study examined clove and cinnamon oil for use in the treatment of mastitis-causing S. aureus biofilms and found them to be effective in reducing preformed biofilms (Budri et al., 2015). Citrus-derived oils (CDO) have recently been shown to inhibit growth of methicillin-resistant $S$. aureus (Muthaiyan et al., $2012 \mathrm{~b}$ ). Therefore, examining its use as an alternative to antibiotic therapy for mastitis is warranted. To the best of our knowledge, no studies have examined the toxicity of CDO on mammary epithelial cells for use as an alternative therapy for mastitis. Our objective was to determine the inhibitory effect of $\mathrm{CDO}$ on the growth of bovine pathogen $S$. aureus, its role in host cell, and invasion of bovine mammary cells (MAC-T) $S$. aureus interactions to explore the potential strategy to control bovine mastitis.

\section{MATERIALS AND METHODS}

\section{Bacterial Strains and Growth Conditions}

Staphylococcus aureus ATCC 29740 was used in this study. This strain has been isolated from bovine mastitic milk. Response time and infection rate of this $S$. aureus strain has been documented previously with consistent changes in onset and duration of the host response beginning as early as $56 \mathrm{~h}$ and continuing through 240 h. (Bannerman, 2009). Bacteria were maintained in nutrient broth or nutrient agar (Gibco, Thermo Fisher Scientific, Waltham, MA) and were grown for 18 to 24 $\mathrm{h}$ before use.

\section{Preparation of CDO}

Terpeneless, cold-pressed Valencia orange oil was provided by Firmenich Citrus Center (Safety Harbor, FL). A stock solution was prepared by dissolving CDO in dimethyl sulfoxide (DMSO; Sigma-Aldrich, St. Louis, MO) to a final concentration of $40 \%$ CDO. However, for the preformed biofilm experiment, a 10\% CDO in DMSO stock solution was needed due to orange oil evaporation. The $10 \%$ stock solution was also used for detection of cytotoxicity.

\section{Determination of MIC}

The broth dilution method was used to determine the MIC of $S$. aureus (Muthaiyan et al., 2012b). Concentrations of CDO ranging from 0.0125 to $0.4 \%$ CDO with half-step dilutions were added to 24-well plates containing $10^{5} \mathrm{cfu} / \mathrm{mL}$ of $S$. aureus. Plates were incubated overnight and MIC was determined as the lowest concentration of CDO inhibiting visual growth of bacteria in the wells of 24-well plate (Greiner Bio-One, Monroe, NC). This was confirmed by colony-forming unit assay.

\section{Growth Inhibition Assay}

Using a spectrophotometer, S. aureus was diluted $10^{8}$ $\mathrm{cfu} / \mathrm{mL}$ in nutrient broth (Difco, Becton, Dickinson and Company, Franklin Lakes, NJ) by adjusting it to an optical density at $600 \mathrm{~nm}\left(\mathbf{O D}_{600}\right)$ of $\sim 0.08$ to 0.12 . This was further diluted to $10^{5} \mathrm{cfu} / \mathrm{mL}$, and placed in cell culture tubes. Staphylococcus aureus was treated with $\mathrm{CDO}$ at concentrations of $0.00,0.05,0.025,0.0125$, and $0.00625 \%$. The control used a concentration of $1 \%$ DMSO. For $4 \mathrm{~h}$, the cell culture tubes were kept in a shaking incubator at $37^{\circ} \mathrm{C}$. We took $100 \mu \mathrm{L}$ of $S$. aureus every $15 \mathrm{~min}$ for $1 \mathrm{~h}$, then every $30 \mathrm{~min}$ for $1 \mathrm{~h}$, and then every $60 \mathrm{~min}$ for a total of $4 \mathrm{~h}$ of incubation. This was serially diluted and plated on to nutrient agar (Difco). Viability was determined by colonies count after overnight culture at $37^{\circ} \mathrm{C}$.

\section{Inhibition of Preformed Biofilms and Biofilm Formation}

The ability of CDO to affect preformed $S$. aureus biofilms and biofilm formation was examined using methods adapted from Karaolis et al. (2005), O'Toole (2011), and Ma et al. (2012). Briefly, bacterial cells were inoculated into nutrient broth and incubated for $18 \mathrm{~h}$. The $\mathrm{OD}_{600}$ of the bacterial suspension was adjusted to $\sim 0.08$ to $0.12\left(10^{8} \mathrm{cfu} / \mathrm{mL}\right)$ and then further diluted with nutrient broth to $10^{7} \mathrm{cfu} / \mathrm{mL}$. To measure CDO 
effect on preformed biofilms, diluted cultures were aliquoted $(200 \mu \mathrm{L})$ into a 96 -well polystyrene flat-bottom microtiter plate (Greiner Bio-One) and incubated statically at $37^{\circ} \mathrm{C}$ for $24 \mathrm{~h}$. Following incubation, the supernatant was removed and fresh nutrient broth $(200 \mu \mathrm{L})$ containing $0,0.025,0.05$, or $0.1 \% \mathrm{CDO}$ was placed in the wells and wrapped with Parafilm (Sigma-Aldrich) for an incubation interval of $24 \mathrm{~h}$ at $37^{\circ} \mathrm{C}$. To measure the effect on biofilm formation, CDO concentrations of $0,0.025,0.05$, or $0.1 \%$ were present in the 96 -well plates during biofilm formation. This plates were then wrapped with Parafilm and incubated statically at $37^{\circ} \mathrm{C}$ for $24 \mathrm{~h}$. After these incubations, the plates were rinsed thrice with distilled water. Afterward, $0.1 \%$ crystal violet $(200 \mu \mathrm{L})$ was added, and the plates were incubated at room temperature for 10 to $15 \mathrm{~min}$. The plates were rinsed thrice and allowed to air dry overnight. Aliquots of $200 \mu \mathrm{L} \mathrm{30 \%} \mathrm{acetic} \mathrm{acid} \mathrm{in} \mathrm{distilled} \mathrm{water} \mathrm{was} \mathrm{used} \mathrm{to}$ dissolve the crystal violet, and plates were shaken for 1 $\mathrm{h}$ before being the solution in each well was transferred to a new 96 -well plate. To determine biofilm growth, the absorbance was measured by a spectrophotometer (Thermo Fisher Scientific) at $540 \mathrm{~nm}$.

\section{Mammalian Cell, Culture, and Monolayer Preparation}

The immortalized MAC-T cell-line was maintained in $75-\mathrm{cm}^{2}$ cell culture flasks in Dulbecco's modified Eagle medium (DMEM; Cellgro, Manassas, VA) supplemented with $10 \%$ fetal bovine serum (FBS) and $100 \mu \mathrm{g}$ of gentamicin $/ \mathrm{mL}$ at $37^{\circ} \mathrm{C}, 5 \% \mathrm{CO}_{2}$.

\section{Inhibition Assay for S. aureus Association and Invasion of MAC-T cells}

The association and invasion assay was carried out according to Salaheen et al. (2014b) with slight modifications. In brief, in a 24 -well plate, $10^{5} \mathrm{MAC}-\mathrm{T}$ cells in $500 \mu \mathrm{L}$ in DMEM supplemented with $10 \%$ FBS were seeded into each well and incubated for $24 \mathrm{~h}$ at $37^{\circ} \mathrm{C}$, $5 \% \mathrm{CO}_{2}$. Staphylococcus aureus was cultured and incubated for $18 \mathrm{~h}$ at $37^{\circ} \mathrm{C}$. Staphylococcus aureus was then diluted to $10^{8} \mathrm{cfu} / \mathrm{mL}$ in nutrient broth by adjusting it to $\mathrm{OD}_{600} \sim 0.08$ to 0.12 . The wells containing MAC-T cells were then washed 3 times before being infected with $10 \mu \mathrm{L}$ of $10^{8} \mathrm{cfu} / \mathrm{mL}$ S. aureus and $1 \mathrm{~mL}$ of DMEM supplemented with $10 \%$ FBS. The multiplicity of infection was 10 . The plates were incubated for $1 \mathrm{~h}$ at $37^{\circ} \mathrm{C}$ with $5 \% \mathrm{CO}_{2}$ to allow time for infection. Wells were then washed thrice with DMEM and treated with DMEM supplemented 10\% FBS and 0, 0.025, 0.05, 0.1, or $0.2 \% \mathrm{CDO}$. The plates were incubated again for 1 $\mathrm{h}$ at $37^{\circ} \mathrm{C}, 5 \% \mathrm{CO}_{2}$. To measure association to MAC$\mathrm{T}$ cells, the cells were washed 3 times with DMEM, treated with $0.1 \%$ Triton X-100, and incubated for 15 $\mathrm{m}$ at $37^{\circ} \mathrm{C}, 5 \% \mathrm{CO}_{2}$. Associated bacterial cells were then serially diluted and plated for enumeration. To measure bacterial invasion of MAC-T cells, cells were first treated with DMEM supplemented with $10 \%$ FBS and $100 \mu \mathrm{g}$ of gentamicin $/ \mathrm{mL}$ for $1 \mathrm{~h}$ at $37^{\circ} \mathrm{C}, 5 \% \mathrm{CO}_{2}$ before the following the same procedure to measure association. This experiment was repeated to determine the effects of treatment with CDO during infection. The only alteration made was the same concentrations of CDO were added to the infection medium during the $1 \mathrm{~h}$ of infection as opposed to afterward.

\section{Detection of Cytotoxicity of CDO for MAC-T Cells}

The 3-(4,5-dimethylthiazol-2-yl)-2,5-diphenyltetrazolium bromide (MTT) assay methods were adapted from Mubarak et al. (2015) and Yousefzadi et al. (2011). From an initial cell suspension of $2 \times 10^{5}$ MAC-T cells, $200 \mu \mathrm{L}$ of this suspension was added into each well, for a final cell population of $\sim 4 \times 10^{4}$ cells/well into a round bottom 96-well plate and incubated for $24 \mathrm{~h}$ at $32^{\circ} \mathrm{C}, 5 \% \mathrm{CO}_{2}$. The medium was removed, and cells were washed 3 times with DMEM before medium was replaced with $200 \mu \mathrm{L}$ of DMEM supplemented with $10 \%$ FBS, $100 \mu \mathrm{g}$ of gentamicin $/ \mathrm{mL}$, and $0,0.025,0.05$, or $0.1 \%$ CDO. This plate was incubated for either 1 or $24 \mathrm{~h}$ at $37^{\circ} \mathrm{C}, 5 \% \mathrm{CO}_{2}$. Medium was removed again and the cells were washed 3 times with DMEM before $200 \mu \mathrm{L}$ of DMEM supplemented with $10 \%$ FBS and $100 \mu \mathrm{g} / \mathrm{mL}$ of gentamicin was added to each well with $20 \mu \mathrm{L}$ of $5 \mathrm{mg} / \mathrm{mL}$ of MTT, reconstituted in $1 \times$ PBS. The cells were incubated for $2 \mathrm{~h}$ to allow reduction of MTT at $37 \mathrm{C}, 5 \% \mathrm{CO}_{2}$. Lysed cells will not react with MTT. Afterward, medium was removed and $200 \mu \mathrm{L}$ of DMSO was added to each well. The 96-well plate was incubated for 10 to $15 \mathrm{~min}$ with shaking before reading at an absorbance of $570 \mathrm{~nm}$. A blank of $100 \%$ DMSO was used.

\section{Statistical Analysis}

One-way ANOVA and Tukey's HSD was carried out using the general linear model according to SAS Institute Inc. (2015) for statistical significance between trials. Results were considered statistically significant mean differences if $P<0.05$.

\section{RESULTS}

\section{MIC of CDO}

The growth of $S$. aureus was inspected after treatment of $\mathrm{CDO}$ at concentrations ranging from 0.0125 to 
$0.4 \%$ for 18 to 24 h. For S. aureus, the MIC was $0.025 \%$ CDO during an 18- to 24 -h period as determined by visual inspection.

\section{Growth Inhibition by CDO on S. aureus}

Staphylococcus aureus growth was reduced at most of the CDO concentrations and time points except incubated in medium containing 0.00625 and $0.0125 \%$ CDO for 15 min (Figure 1). All CDO concentrations were capable of significant reductions in $S$. aureus bacterial cell count, but the magnitude and speed of this inhibitory action depended on concentration. After only $15 \mathrm{~min}$, the $0.05 \%$ and $0.025 \% \mathrm{CDO}$ trials created statistically significant $(P<0.05)$ reductions compared with the DMSO trial, with an average of $4.39 \pm 0.12$ and 4.61 $\pm 0.21 \log \mathrm{cfu} / \mathrm{mL}$, respectively, compared with $4.78 \pm$ $0.35 \log \mathrm{cfu} / \mathrm{mL}$ in the DMSO control. After $30 \mathrm{~min}$, $0.0125 \% \mathrm{CDO}$ reduced the bacterial counts to 4.1126 $\pm 0.62 \log \mathrm{cfu} / \mathrm{mL}$, which is a statistically significant $(P<0.05)$ decrease in bacterial count from the DMSO control at $4.82 \pm 0.26 \log \mathrm{cfu} / \mathrm{mL}$. At the lowest concentration used $(0.00625 \% \mathrm{CDO})$, the numbers of $S$. aureus were reduced from $4.98 \pm 0.14$ to $4.15 \pm 0.21 \mathrm{log}$ $\mathrm{cfu} / \mathrm{mL}$ over the 4 -h time period. This reduction begins around 60 min of exposure, when numbers of $S$. aureus were $4.78 \pm 0.05 \log \mathrm{cfu} / \mathrm{mL}$, which is statistically significant $(P<0.05)$ from the DMSO control trial at 5.02 $\pm 0.22 \log \mathrm{cfu} / \mathrm{mL}$. All trials show further reduction at every following interval. Some concentrations were able to effectively eliminate $S$. aureus below detectable limits. At a concentration of $0.025 \% \mathrm{CDO}$, no $S$. aureus was recovered after $180 \mathrm{~min}$; at a higher concentration of $0.05 \% \mathrm{CDO}$, no $S$. aureus was recovered after 120 min. However, S. aureus was only reduced to $2.70 \pm$ $0.12 \log \mathrm{cfu} / \mathrm{mL}$ at a concentration of $0.0125 \%$ after $4 \mathrm{~h}$. Lower concentrations also failed to eliminate $S$. aureus below detectable limits.

\section{Effect of CDO on Preformed S. aureus Biofilms and Biofilm Formation}

Citrus-derived oil's effect on preformed $S$. aureus biofilms is shown in Figure 2. These biofilms were formed in 96-well plates over $24 \mathrm{~h}$ before being treated with CDO for another $24 \mathrm{~h}$. Concentrations of CDO used were $0,0.025,0.05$, and $0.1 \%$ in nutrient broth. Absorbance in each well was measured at $540 \mathrm{~nm}\left(\mathbf{A}_{\mathbf{5 4 0}}\right)$. No statistical difference in absorbance was noted in biofilm growth among 0 (control), 0.025, and 0.1\% CDO. However, a statistically significant $(P<0.05)$ difference in biofilm growth was observed between $0.05 \% \mathrm{CDO}\left(\mathrm{A}_{540}\right.$ $=0.056)$ and the control $\left(\mathrm{A}_{540}=0.061\right)$. Unlike the preformed biofilm, during biofilm formation $S$. aureus

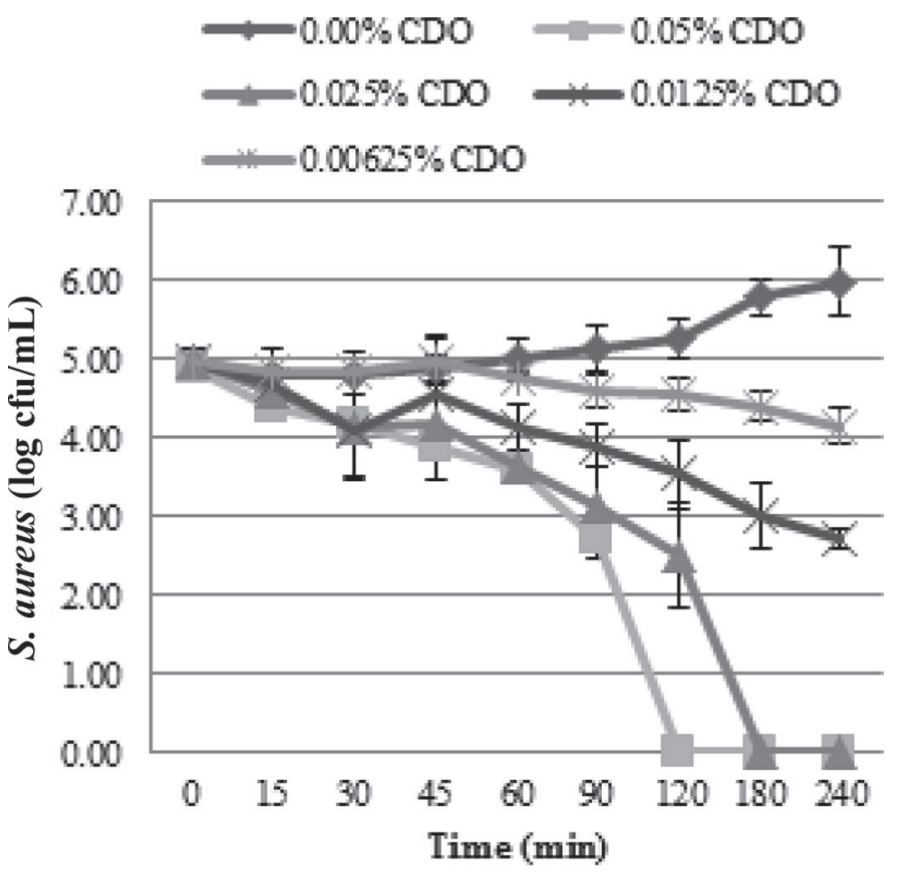

Figure 1. Growth inhibition of Staphylococcus aureus during a 4-h treatment with $0.00,0.05,0.025,0.0125$, and $0.00625 \%$ citrus-derived oil (CDO). Log cfu/mL for both bacteria were measured after 0,15 , $30,45,60,90,120,180$, and $240 \mathrm{~min}$. A starting concentration of $10^{5}$ $\mathrm{cfu} / \mathrm{mL}$ was used for all trials.

failed to form a biofilm in the presence of $0,0.025,0.05$, and $0.1 \% \mathrm{CDO}$ in broth.

\section{Inhibition of Association and Invasion of S. aureus to MAC-T Cells with CDO}

Figure 3 displays quantities of $S$. aureus recovered from MAC-T cells after CDO treatments. Staphylococ-

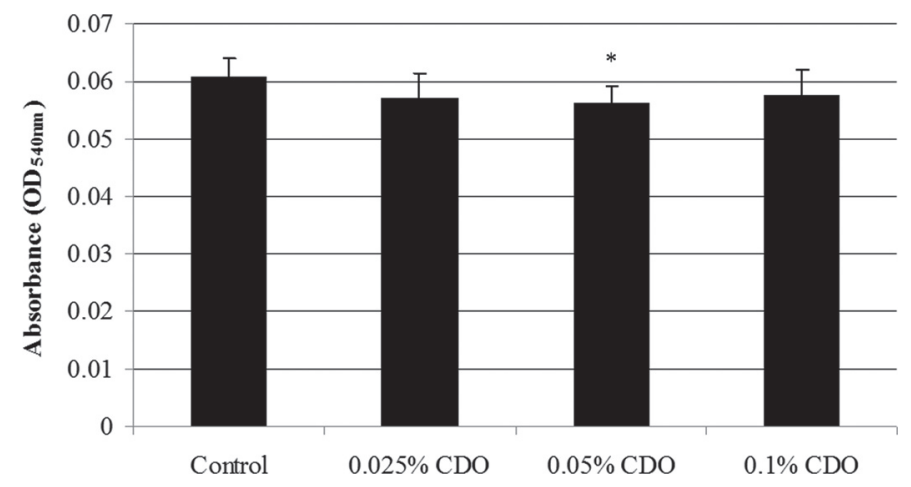

Figure 2. The effect of citrus-derived oil (CDO) on absorbance in preformed Staphylococcus aureus biofilms. Absorbance at $540 \mathrm{~nm}$ was measured for the CDO concentrations of $0,0.025,0.05$, and $0.1 \%$. An asterisk $(*)$ indicates significant difference $(P<0.05)$ from $0 \%$ control based on one-way ANOVA and Tukey honestly significant difference (HSD). 
cus aureus with MAC-T cells were treated for $1 \mathrm{~h}$ with range of $\mathrm{CDO}$ conditions, starting at $0.2 \%$ with halfstep dilutions down to $0.025 \%$ and a control using $1 \%$ of DMSO. Associated bacteria are those adhered to and invaded in host cells combined. Citrus-derived oil had an effect on association of $S$. aureus to MAC-T cells at the highest concentrations tested. No bacterial cells were recovered after treating with 0.1 and $0.2 \% \mathrm{CDO}$ for $1 \mathrm{~h}$. These results were statistically significant at $P$ $<0.05$. Association of $S$. aureus to MAC-T cells were 46 and $70 \%$ reduced in 0.025 and $0.05 \%$ CDO-treated groups compared with the nontreated control, respectively (Figure 3 ). However, these results were not found to be statistically significant $(P>0.05)$.

Citrus-derived oil was shown to inhibit invasion of $S$. aureus specifically, as well. A bar graph depicting these data is displayed in Figure 4. The concentrations of CDO tested were identical to those used in the association assay. Concentrations as low as $0.5 \% \mathrm{CDO}$ were capable of inhibiting invasion by $S$. aureus. For $S$. aureus in $0.025 \%$ CDO, bacterial count decreased from 3.19 to $2.45 \log \mathrm{cfu} / \mathrm{mL}$. At concentrations of $0.05 \%$ $\mathrm{CDO}$ and above, $S$. aureus was no longer detectable. When MAC-T cells were treated with CDO during infection, no associated nor invaded $S$. aureus was recovered when using concentrations ranging from 0.025 to $0.2 \%$ (data not shown).

\section{Cytotoxicity of CDO on MAC-T cells}

The concentrations of CDO that has been used in our study showed no cytotoxic effect on MAC-T cells after $1 \mathrm{~h}$, which is displayed in Figure 5. The CDO concentrations start at $0.025 \%$ with half-step dilutions up to $0.1 \%$. At the lowest concentrations, CDO was able to increase proliferation after $1 \mathrm{~h}$. Relative cytotoxicity was measured $-38.0 \%$ for $0.025 \% \mathrm{CDO}$ and $-42.2 \%$ for $0.05 \% \mathrm{CDO}$; however, at the highest concentration, $0.1 \%$, no effect on MAC-T cells was observed. The relative cytotoxicity measured for $0.1 \%$ CDO was $-13.5 \%$, which was not significantly different $(P<0.05)$ from the baseline. After $24 \mathrm{~h}$, cytotoxicity was $79.9,66.3$, and $52.1 \%$ for concentrations of $0.025,0.05$, and $0.1 \%$ CDO, respectively.

\section{DISCUSSION}

The effects antimicrobial effects of CDO have been well documented, but most studies have focused on its effects on foodborne pathogens. Our study aimed to test the antimicrobial properties of CDO on a common mastitis-causing pathogen, $S$. aureus. The strain of $S$. aureus used was isolated from the milk of cows with mastitis as opposed to strains found in foodborne infec-

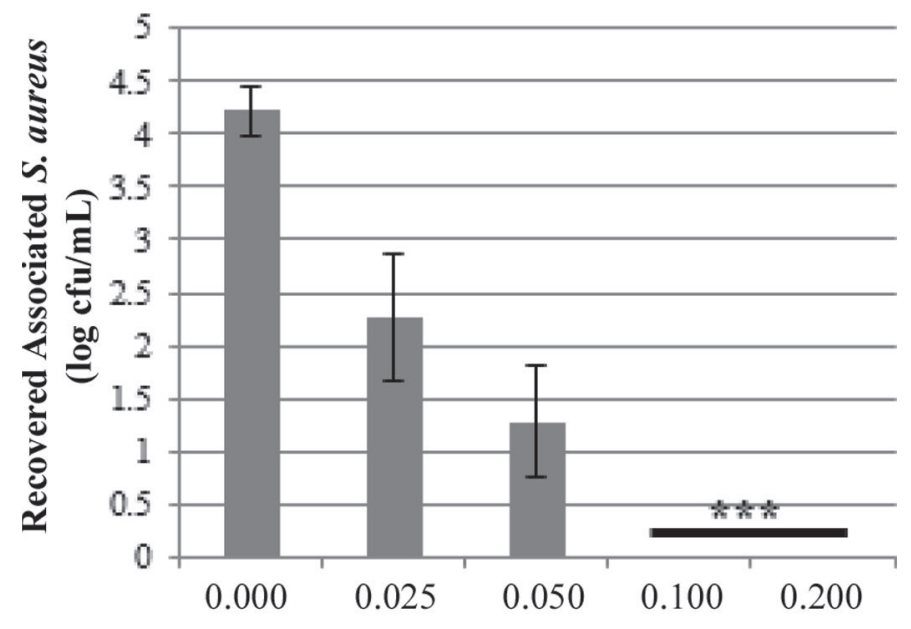

CDO Treatment (\%)

Figure 3. Recovered associated $\log \mathrm{cfu} / \mathrm{mL}$ of Staphylococcus aureus with invasion of bovine mammary cells (MAC-T) cells after a 1-h treatment with range of citrus-derived oils (CDO) starting at $0.2 \%$ with half-step dilutions down to $0.025 \%$. The control had an equivalent volume of dimethyl sulfoxide added to the wells. Associated bacteria include those invaded or attached to MAC-T cells. Significant differences were found $(P<0.05)$ in $\log \mathrm{cfu} / \mathrm{mL}$ of associated bacteria in $S$. aureus when compared among groups. Concentrations significantly different $(P<0.05)$ are marked with asterisks $(*)$. There was a significant $\mathrm{CDO}$ concentration effect $(P<0.05)$.

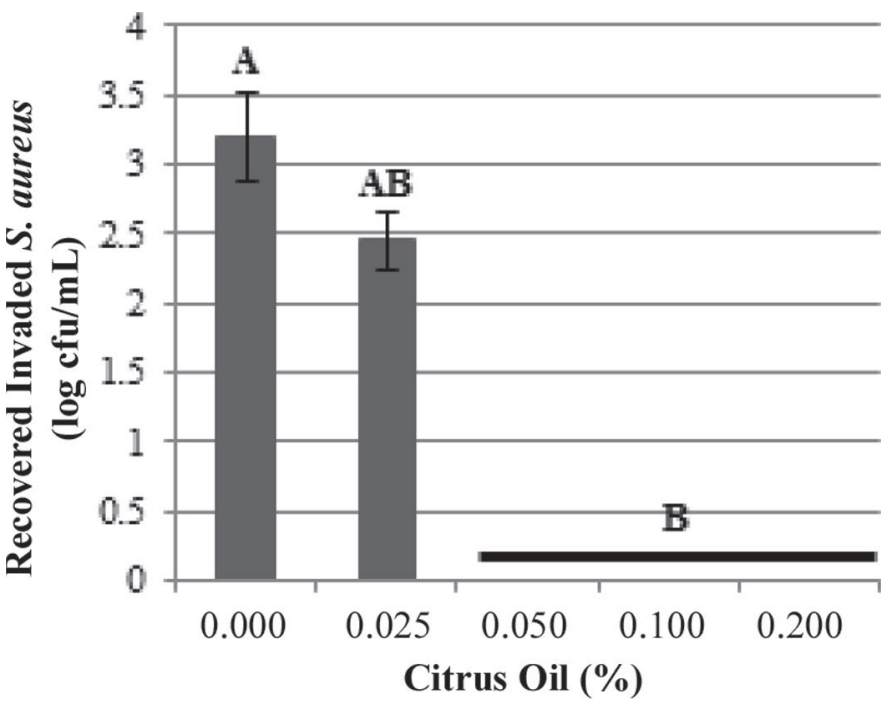

Figure 4. Invasion of invasion of bovine mammary cells (MAC-T) cells by Staphylococcus aureus under a range of citrus-derived oils (CDO) conditions starting at $0.2 \%$ with half-step dilutions down to $0.025 \%$. These MAC-T cells were treated with their respective citrus oil condition for $1 \mathrm{~h}$. A concentration of $0 \%$ CDO was used a control. Invasion of MAC-T cells was measured after $1 \mathrm{~h}$ of treatment. Concentrations significantly different $(P<0.05)$ are marked with uppercase letters (A, B). There was a significant CDO concentration effect $(P<0.05)$ based on one-way ANOVA and Tukey honestly significant difference (HSD) test. 


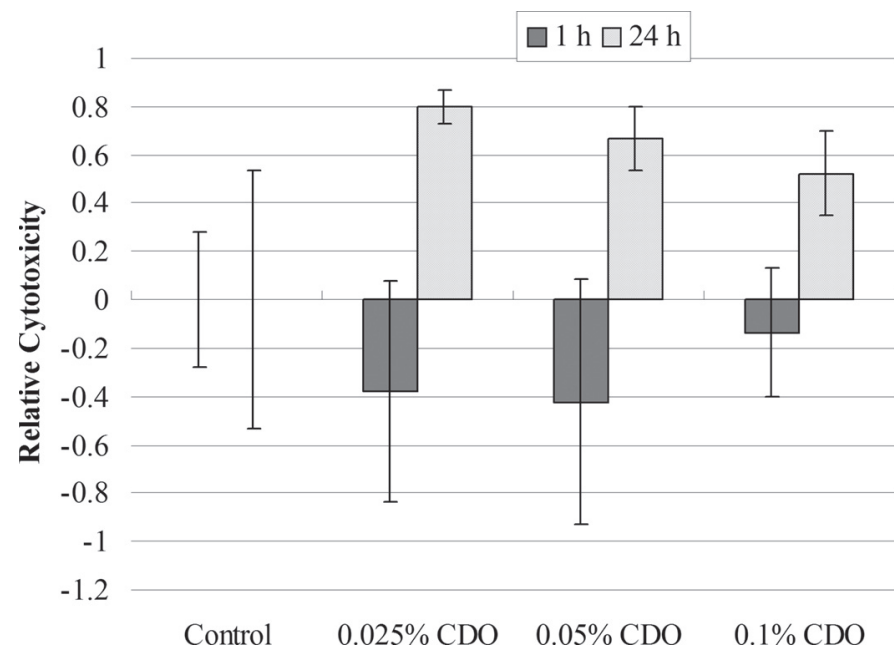

Figure 5. Relative cytotoxicity of citrus-derived oils (CDO) on invasion of bovine mammary cells (MAC-T) cells measured after 1 and $24 \mathrm{~h}$ of treatment with concentrations of CDO starting at $0.025 \%$ with half-step dilutions up to $0.1 \%$. A control of only Dulbecco's modified Eagle medium (DMEM; Cellgro, Manassas, VA) supplemented with $10 \%$ fetal bovine serum and $100 \mu \mathrm{g} / \mathrm{mL}$ of gentamicin was used for the $0 \%$ CDO treatment.

tion. However, studies done on food-borne strains of $S$. aureus suggest $\mathrm{CDO}$ will be effective against $S$. aureus strains associated with mastitis, as CDO acts on the cell wall of the bacteria (Muthaiyan et al., 2012b).

In our study, we investigated antimicrobial properties of CDO on $S$. aureus and it was fast and effective. We identified that MIC of CDO was $0.025 \%$ on growth of S. aureus after 18 to $24 \mathrm{~h}$ of incubation. This is far lower than the MIC of $0.18 \%$ that has been shown for other strains of $S$. aureus (Muthaiyan et al., 2012b). However, the MIC for $S$. aureus is variable depending on strain, with another study reporting a MIC of $0.5 \%$ (Espina et al., 2011). Even low concentrations of CDO, such as $0.00625 \%$, also inhibited $S$. aureus growth in a time kill curve assay. Citrus-derived oil inhibited $S$. aureus growth in all CDO treatments compared with a 1\% DMSO treatment. Staphylococcus aureus was eliminated below detectable limits in medium containing 0.025 and $0.05 \% \mathrm{CDO}$ after 180 and $120 \mathrm{~min}$ of incubation, respectively (Figure 1). This is consistent with findings in another study that showed a $0.1 \%$ concentration of orange oil and orange terpeneless oil was effective at eliminating S. aureus growth by $100 \%$ (Dabbah et al. 1970), as elimination of S. aureus below detectable limits occurs at $0.025 \%$ CDO or higher. Various proposed mechanisms of action exist for this result. The first is that the essential oils cause damage to the cell well (Helander et al., 1998; Muthaiyan et al., $2012 \mathrm{~b}$ ); the second is the essential oils cause damage to the cell membrane and mitochondrial membrane (Burt,
2004). This is due to the fact the essential oils tend to be hydrophobic, so they disrupt the membrane, increasing membrane permeability (Burt, 2004; Fisher and Phillips, 2008). The third is that essential oils damage membrane proteins. All of these mechanisms can result in leakage of ions and nutrients out of the cell (Fisher and Phillips, 2008).

The effect of CDO on preformed $S$. aureus biofilms was tested in our study. Staphylococcus aureus biofilms play a role in chronic and recurrent mastitis infections, allowing the infection to hide from antimicrobials (Melchior et al., 2006). To our knowledge, no other study has examined the effect of CDO alone on $S$. aureus biofilms. However, other essential oils have been documented to inhibit S. aureus and Staphylococcus epidermis biofilms (Solórzano-Santos and Miranda-Novales, 2012). In addition, one study used a 1:1 blend of orange oil and bergamot oil to inhibit $S$. aureus (Laird et al., 2012). Modest reductions in organisms were noted after a 24-h exposure (Laird et al., 2012). After growing biofilms for 18 to $24 \mathrm{~h}$, CDO treatment was applied and the absorbance at $\mathrm{OD}_{570}$ was measured. Citrus-derived oil was shown to only have a modest effect on biofilms at a concentration of $0.05 \%$, but no effect at 0.025 and $0.1 \%$. This is similar to the action of some antibiotics on biofilms (Kaplan, 2011). Induction of biofilms is often seen at low doses, and occasionally at high ones as well, creating a U-shaped dip in which the antibiotic is most effective (Kaplan, 2011). These U-shaped dose response curves are part of a biological phenomenon called hormesis (Kaplan, 2011). Low doses of antibiotics are capable of inducing transcription, with about $5 \%$ of bacterial promoters being upregulated during exposure (Kaplan, 2011). Notably, biofilm formation appears to be upregulated by some low doses of antibiotics in some bacteria, such as rifampin on S. epidermis (Kaplan, 2011). It is possible that orange oil is acting in a similar manner to antibiotics and is inducing transcription of biofilm genes at lower concentrations. Highdose stimulation is also seen in other bacteria during high-dose antibiotic exposure (Kaplan, 2011). As CDO is a modest inhibitor of preformed biofilms, it may be unable to limit chronic cases of mastitis except when used in moderate doses. However, CDO has potential as a preventative against biofilm formation as $S$. aureus was unable to form a biofilm in its presence.

We then used MAC-T cells for an in vitro model of CDO effect on $S$. aureus in a mammary gland. Inhibition of association was tested. Association measures adherence as well as invasion were combined. Infection by $S$. aureus begins with adhesion to bovine mammary gland cells, and adherence is the initial step in pathogenesis (Kerro Dego et al., 2002). A concentration of $0.1 \% \mathrm{CDO}$ or higher was required to significantly 
inhibit association by $S$. aureus to MAC-T cells (Figure 3); inhibition of invasion was then tested. Chronic mastitis by $S$. aureus is a large problem, caused by invasion into the cell, as antimicrobials typically only affect extracellular bacteria (Barkema et al., 2006). Therefore, treatments are needed that can prevent and inhibit intracellular invasion. In MAC-T cells, it only took a concentration of $0.025 \% \mathrm{CDO}$ to inhibit invasion by $S$. aureus significantly from $2.34 \times 10^{4}$ to $6.17 \times 10^{2} \mathrm{cfu} / \mathrm{mL}$. Higher concentrations resulted in greater reductions in bacterial count. Other studies have documented orange oil's ability to eliminate $S$. aureus from infected keratinocytes after using a concentration of $0.2 \%$ to treat cells (Muthaiyan et al., 2012a). Invasion of $S$. aureus into bovine mammary cells is thought to be caused by $S$. aureus producing factors that mobilize $\mathrm{F}$ actin microfilaments in the bovine cell cytoskeleton, allowing the bacteria to be internalized through endocytosis (Almeida et al., 1996). Binding to fibronectin appears to be necessary and sufficient for adhesion as well as invasion (Kerro Dego et al., 2002; Menzies, 2003). Staphylococcus aureus has fibronectin binding proteins on the surface of the cell membrane (Menzies, 2003). It is possible CDO disrupts fibronectin binding proteins, preventing endocytosis of $S$. aureus, but further study is required.

Determination of any cytotoxic effect of $\mathrm{CDO}$ on bovine mammary epithelial cells is necessary to ensure safety if used in vivo. Cytotoxicity of CDO was tested on MAC-T cells to model in vivo bovine mammary epithelial cells. Citrus-derived oil did not have a cytotoxic effect on MAC-T cells at $1 \mathrm{~h}$ of treatment. Its proliferation-stimulating effect at concentrations of 0.025 and $0.5 \%$ may even serve to reverse damage to udder tissue following mastitis infection. However, at $24 \mathrm{~h}$ of treatment, the cytotoxic effect was high, particularly at the lowest concentrations. Reduced inhibition at higher dosages is another example of hormesis (Calabrese and Baldwin, 2001). To our knowledge, no studies have examined the effect of CDO on bovine mammary cells; however, a study found that CDO has no effect on mice macrophage cells at concentrations of 0.025 and $0.05 \%$ (Zacaro Scelza et al., 2006). From both of these studies, it does not appear that CDO negative affects cell viability during short-term exposure, such as in a lactating cow when milk would substantially dilute CDO treatment after $1 \mathrm{~h}$. In vivo conditions tend to be more tolerant of cytotoxic substances, so further study should be done in vivo for both short and long-term exposure.

In the current study, we provided evidence that CDO has an antimicrobial effect on S. aureus. Our data suggest that CDO has the potential to be used as a pre- ventive and treatment for $S$. aureus-mediated mastitis. Further studies should be carried out to investigate the side effects of CDO on $S$. aureus, such as inhibition of the release of exotoxins, inhibition of autoaggregation, and hydrophobic action. In addition, more work should be done to examine its antibiofilm properties, including its effects on biofilm growth across a greater range of concentrations as well as how it affects gene expression of biofilm mediatory genes. To ensure its safety for cattle, more research must be carried out to determine CDO effects on MAC-T cells, such as cytokine production and milk synthesis.

\section{ACKNOWLEDGMENTS}

We thank Firmenich Inc. (Lakeland, FL) for kindly providing us with the citrus oil. Funding for D. Biswas provided by Star up package (FRS \# 2-93108).

\section{REFERENCES}

Ahn, J., J. A. Almario, S. Salaheen, and D. Biswas. 2014. Physicochemical, mechanical, and molecular properties of nonlysogenic and p22-lysogenic Salmonella Typhimurium treated with citrus oil. J. Food Prot. 77:758-764.

Almeida, R. A., K. R. Matthews, E. Cifrian, A. J. Guidry, and S. P. Oliver. 1996. Staphylococcus aureus invasion of bovine mammary epithelial cells. J. Dairy Sci. 79:1021-1026.

Alzoreky, N. S., and K. Nakahara. 2003. Antibacterial activity of extracts from some edible plants commonly consumed in Asia. Int. J. Food Microbiol. 80:223-230.

Bannerman, D. D. 2009. Pathogen-dependent induction of cytokines and other soluble inflammatory mediators during intramammary infection of dairy cows. J. Anim. Sci. 87:10-25.

Bar, D., L. W. Tauer, G. Bennett, R. N. González, J. A. Hertl, Y. H. Schukken, H. F. Schulte, F. L. Welcome, and Y. T. Gröhn. 2008. The cost of generic clinical mastitis in dairy cows as estimated by using dynamic programming. J. Dairy Sci. 91:2205-2214.

Barkema, H. W., Y. H. Schukken, and R. N. Zadoks. 2006. Invited review: The role of cow, pathogen, and treatment regimen in the therapeutic success of bovine Staphylococcus aureus mastitis. J. Dairy Sci. 89:1877-1895.

Barlow, J. 2011. Mastitis therapy and antimicrobial susceptibility: A multispecies review with a focus on antibiotic treatment of mastitis in dairy cattle. J. Mammary Gland Biol. Neoplasia 16:383-407.

Botrel, M. A., M. Haenni, E. Morignat, P. Sulpice, J. Madec, and D. Calavas. 2010. Distribution and antimicrobial resistance of clinical and subclinical mastitis pathogens in dairy cows in Rhone-Alopes, France. Foodborne Pathog. Dis. 7:479-487.

Budri, P. E., N. C. Silva, E. C. Bonsaglia, F. A. Júnior, A. J. P. Júnior, J. T. Doyama, J. L. Gonçalves, M. V. Santos, D. FitzgeraldHughes, and V. L. Rall. 2015. Effect of essential oils of Syzygium aromaticum and Cinnamomum zeylanicum and their major components on biofilm production in Staphylococcus aureus strains isolated from milk of cows with mastitis. J. Dairy Sci. 98:5899-5904.

Burt, S. 2004. Essential oils: their antibacterial properties and potential applications in foods-A review. Int. J. Food Microbiol. 94:223-253.

Burt, S. A., and R. D. Reinders. 2003. Antibacterial activity of selected plant essential oils against Escherichia coli O157:H7. Lett. Appl. Microbiol. 36:162-167.

Calabrese, E. J., and L. A. Baldwin. 2001. U-shaped dose-responses in biology, toxicology, and public health. Annu. Rev. Public Health 22:15-33. 
Craven, N. 1987. Efficacy and financial value of antibiotic treatment of bovine clinical mastitis during lactation-A review. Br. Vet. J. 143:410-422.

Dabbah, R., V. M. Edwards, and W. A. Moats. 1970. Antimicrobial action of some citrus fruit oils on selected food-borne bacteria. Appl. Microbiol. 19:27-31.

Espina, L., M. Somolinos, S. Lorán, P. Conchello, D. García, and R. Pagán. 2011. Chemical composition of commercial citrus fruit essential oils and evaluation of their antimicrobial activity acting alone or in combined processes. Food Contr. 22:896-902.

Fisher, K., and C. Phillips. 2008. Potential antimicrobial uses of essential oils in food: Is citrus the answer? Trends Food Sci. Technol. 19:156-164.

Guterbock, W. M., A. L. Van Eenennaam, R. J. Anderson, I. A. Gardner, J. S. Cullor, and C. A. Holmberg. 1993. Efficacy of intramammary antibiotic therapy for treatment of clinical mastitis caused by environmental pathogens. J. Dairy Sci. 76:3437-3444.

Harmon, R. J. 1994. Physiology of mastitis and factors affecting somatic cell counts. J. Dairy Sci. 77:2103-2112.

Helander, I. M., H. Alakomi, K. Latva-Kala, T. Mattila-Sandholm, I. Pol, E. J. Smid, L. G. M. Gorris, and A. von Wright. 1998. Characterization of the action of selected essential oil components on gram-negative bacteria. J. Agric. Food Chem. 46:3590-3595.

Kaplan, J. B. 2011. Antibiotic-induced biofilm formation. Int. J. Artif Organs 34:737-751.

Karaolis, D. K. R., M. H. Rashid, R. Chythanya, W. Luo, M. Hyodo, and Y. Hayakawa. 2005. c-di-GMP (3'-5'-Cyclic Diguanylic Acid) inhibits Staphylococcus aureus cell-cell interactions and biofilm formation. Antimicrob. Agents Chemother. 49:1029-1038.

Kerro Dego, O., J. E. van Dijk, and H. Nederbragt. 2002. Factors involved in the early pathogenesis of bovine Staphylococcus aureus mastitis with emphasis on bacterial adhesion and invasion. A review. Vet. Q. 24:181-198.

Laird, K., D. Armitage, and C. Phillips. 2012. Reduction of surface contamination and biofilms of Enterococcus sp. and Staphylococcus aureus using a citrus-based vapor. J. Hosp. Infect. 80:61-66.

Ma, Y., Y. Xu, B. D. Yestrepsky, R. J. Sorenson, M. Chen, S. D. Larson, and H. Sun. 2012. Novel inhibitors of Staphylococcus aureus virulence gene expression and biofilm formation. PLoS ONE 7:e47255.

Melchior, M. B., H. Vaarkamp, and J. Fink-Gremmels. 2006. Biofilms: A role in recurrent mastitis infections? Vet. J. 171:398-407.

Menzies, B. E. 2003. The role of fibronectin binding proteins in the pathogenesis of Staphylococcus aureus infections. Curr. Opin. Infect. Dis. 16:225-229.

Moser, A., R. Stephan, S. Corti, and S. Johler. 2013. Comparison of genomic and antimicrobial resistance features of latex agglutination test-positive and latex agglutination test-negative Staphylococcus aureus isolates causing bovine mastitis. J. Dairy Sci. 96:329-334.

Mubarak, E. E., L. Z. Ali, I. F. A. Ahmed, and A. B. Ali. 2015. Essential oil compositions and cytotoxicity from various organs of eucalyptus camaldulensis. Int. J. Agric. Biol. 17:320-326.

Muthaiyan, A., D. Biswas, P. Crandall, B. Wilkinson, and S. Ricke. 2012a. Application of orange essential oil as an antistaphylococ- cal agent in a dressing model. BMC Complement. Altern. Med. $12: 125-130$.

Muthaiyan, A., E. M. Martin, S. Natesan, P. G. Crandall, B. J. Wilkinson, and S. C. Ricke. 2012b. Antimicrobial effect and mode of action of terpeneless cold-pressed Valencia orange essential oil on methicillin-resistant Staphylococcus aureus. J. Appl. Microbiol. 112:1020-1033.

O'Toole, G. A. 2011. Microtiter dish biofilm formation assay. J. Vis Exp. 2011:2437.

Paape, M. J., D. D. Bannerman, X. Zhao, and J. W. Lee. 2003. The bovine neutrophil: Structure and function in blood and milk. Vet. Res. 34:597-627.

Reyher, K. K., D. Haine, I. R. Dohoo, and C. W. Revie. 2012. Examining the effect of intramammary infections with minor mastitis pathogens on the acquisition of new intramammary infections with major mastitis pathogens-A systematic review and meta-analysis. J. Dairy Sci. 95:6483-6502.

Salaheen, S., J. A. Almario, and D. Biswas. 2014b. Inhibition of growth and alteration of host cell interactions of Pasteurella multocida with natural byproducts. Poult. Sci. 93:1375-1382.

Salaheen, S., C. Nguyen, D. Hewes, and D. Biswas. 2014a. Cheap extraction of antibacterial compounds of berry pomace and their mode of action against the pathogen Campylobacter jejuni. Food Contr. 46:174-181.

SAS Institute Inc. 2015. SAS On Demand: Studio, Version 3.4. SAS Institute Inc., Cary, NC.

Seegers, H., C. Fourichon, and F. Beaudeau. 2003. Production effect related to mastitis and mastitis economics in dairy cattle herds. Vet. Res. 34:475-491.

Smith-Palmer, A., J. Stewart, and L. Fyfe. 1998. Antimicrobial properties of plant essential oils and essences against five important food-borne pathogens. Lett. Appl. Microbiol. 26:118-122.

Sol, J., O. C. Sampimon, H. W. Barkema, and Y. H. Schukken. 2000 Factors associated with cure after therapy of clinical mastitis caused by Staphylococcus aureus. J. Dairy Sci. 83:278-284.

Solórzano-Santos, F., and M. G. Miranda-Novales. 2012. Essential oils from aromatic herbs as antimicrobial agents. Curr. Opin. Biotechnol. 23:136-141.

Tikofsky, L. L., J. W. Barlow, C. Santisteban, and Y. H. Schukken. 2003. A comparison of antimicrobial resistance susceptibility patterns for Staphylococcus aureus in organic and conventional dairy herds. Microb. Drug Resist. 9:S39-S45.

Yang, H., D. Hewes, S. Salaheen, C. Federman, and D. Biswas. 2014 Effects of blackberry juice on growth inhibition of foodborne pathogens and growth promotion of Lactobacillus. Food Contr. 37:15-20.

Yousefzadi, M., M. Heidari, M. Akbarpour, M. H. Mirjalili, A. Zeinali, and M. Parsa. 2011. In vitro cytotoxic activity of the essential oil of Dorema ammoniacum D. Don. Middle East J. Sci. Res. $7: 511-514$

Zacaro Scelza, M. F., L. R. L. Oliveira, F. B. Carvalho, and S. C. Faria. 2006. In vitro evaluation of macrophage viability after incubation in orange oil, eucalyptol, and chloroform. Oral Surg. Oral Med. Oral Pathol. Oral Radiol. Endod. 102:e24-e27. 